who has visited Kulja, gave an interesting account of his experiences in that region a few years back.

FEARs had been entertained by many that the expedition sent out by the Russian merchant M. Alexander Sibiriakoff to discover the North Passage by means of the steamer Oscar Dickson, on board of which M. Sibiriakoff was himself, had been lost, and M. Konstantin Sibiriakoff, his brother, had already equipped another expedition to find and assist the Oscar Dickson. In the meantime the welcome news has arrived that Alexander Sibiriakoff reached Tobolsk at the end of December. The Oscar Dickson and another sbip, the Nordland, had met fresh ice near Mate-Ssale, and had retired into the Gydan Bay on the coast of Siberia, in order to winter there.

M. TARRY, a member of the French Commission for TransSaharan Communications, is stated to have discovered in the south of Wargla the ruins of a large city called Cedrada, which had been entombed by sands of the desert. This city is placed in the Valley of Wed Mya, and in the vicinity of a number of sources which in former centuries watered thousands of palmtrees. Orders have been sent to procure a set of sounding apparatus, and it is expected a large quaniity of pure water will be extracted from the earth. M. Tarry published an appeal to the local papers in order to obtain from the Government the foundation of a colony in this remote region.

\section{DEEP-SEA EXPLORATION}

II.

4. FOOD. - The late Prof. Sars, in his remarks on the distribution of animals in the depths of the sea, asks "Whence do animals that live at depths far below the limits of vegetation obtain their food?" Bronn, Wallich, Wyville Thomson, and others have endeavoured to answer this question; but I do not think the problem has yet been satisfactorily solved. A considerable quantity of vegetable food is undoubtedly supplied from the Sargasso Sea and a similar area in the Pacific Ocean, as well as by the sea-weeds which fringe every coast. But this supply is not sufficient for the indirect support of the countless host of animals that inhabit the depths of the ocean, all of which are necessarily zoophagous or subsist on other animals. Plant life, except perhaps one of a peculiar kind, which will be presently noticed, appears to be absent in depths exceeding 150 fathoms.

In all probability the chief supply of vegetable food is de rived from the countless diatoms, coccoliths, rhabdoliths, and oscillatorix, which are plants of a low degree of organisation, and swarm on the surface of the sea; these are swallowed by pelagic animals (such as Salpz and Pteropods, or "sea-butterflies "), and the latter fall to the bottom after death, and form that flocculent or glairy mass which $I$ have described in the Report of the Porcupine Expedition of 1869 as covering the bed of the North Atlantic at great depths. ${ }^{2}$ The preservative effect of sea-water on animal tissues would stay decomposition for a long while ; and Mr. Moseley ascertained by a curious experiment that it would take only about four days for a Salpa to reach the bottom at a depth of 2000 fathoms, and that the Salpa was not greatly decomposed after having remained in sea-water for a month in the tropics.

When we say that vegetable life does not exist at any considerable depth, we must not forget that some kind is said to occur in great abundance even in the benthal or deepest zone. The word "benthal" is applied to depths exceeding rooo fathoms (see my Address, which is referred to hereafter in this lecture). Shells, corals, and other organisms, are everywhere permeated by what are considered to be minute plants allied to fangi or confervæ, which form branching canals, like those of the Cliona or perforating sponge; and such canals have been also detected in all fossiliferous strata of a marine nature, from the Silurian to the present epoch. These plants, or Thallophytes, have been called "parasitic"; but they do not live on any other living thing. They can hardly serve as food for deep-sea animals, because they are never exposed. Whether they may not be a link to connect the animal and vegetable kingdoms may be a matter for further investigation.

Food is of course a very important factor as regards the size of all animals. I have noticed, in my work on "British Conchology,"

${ }^{I}$ A Lecture by J. Gwyn Jeffreys, LL.D., F.R.S. Given at Swansea, Llanelly, and Barrow-in-Furness, in December 1880 and January 188 Continued from p. 302 .

${ }_{2}$ See Proc. Roy. Soc. 1870, p. 420. that Mollusca from moderate depths are generally larger than those of the same species from shallow water; but this does not seem to be the case with a species of coral obtained in the Challenger Expedition, which ranged from a depth of 30 to one of 2900 fathoms, and was very variable in size.

5. Light.-Milton tells us of the

$$
\text { "world of waters dark and deep." }
$$

One of the most interesting problems relating to the subject of this lecture is whether the above is a poetical idea or based on fact, as regards the absence of light in the abysses of the ocean.

We do not know to what extent the sun's rays penetrate the sea, nor whether the bottom at all depths is absolutely devoid of light. An ingenious apparatus, which was contrived by Dr. Siemens for ascertaining the presence of light at different depths by means of highly sensitive photographic paper, has never yet been properly tried. An experiment of this kind made by Prof. Forel proved that in the Lake of Geneva, even at a depth of only thirty fathoms, the paper was entirely unaffected after protracted exposure. But the water of that lake is peculiar; it is said to be rendered less transparent by suspended and floating particles of mica brought from glacier streams, and to have thus acquired its deep blue colour. I cannot believe that the only abyssal light, if there be any, is phosphorescent.

At all events we are certain that, as regards the sea, many animals at very great depths have eyes, and that there is no absence of colour.

Cuttlefishes, which bave eyes not less highly organised than our own, have frequently been obtained from depths of many hundred fathoms ; they do not eat phosphorescent polypes and such small deer. Nor are the deep-sea Mollusca blind, During the Porcupine Expedition of 1869 an undescribed species of Pleurotroma from 2090 fathoms had a pair of well-developed eyes on short footstalks; and a Fusus from 1207 fathoms had its eyes at the base of the tentacles. The last-named mollusks chiefly prey on bivalves. I have taken at moderate depths, living on the same ground, closely-allied species of univalve mollusks, some of which were eyeless or blind, and others were provided with the usual organs of vision. Numerous instances have been given by the Challenger naturalists of apparently seeing as well as of apparently sightless animals taken at great depths. Prof. Semper, of Wuirzburg, says, in "The Natural Conditions of Existence as they Affect Animal Life" (I88I), "Many creatures furnished with well-constructed eyes live associated with the actually blind species, and which have been partly enumerated above." He mentions among the former five species of fish (one of a new genus) discovered in the Challenger Expedition at depths of from 675 to 2040 fathoms, besides several Mollusca and Crustacea.

Some land-slugs and mollusks (e.g. Geomalacus maculosus and Achatina acicula) are also blind. On the sea-shore and in shallow water most bivalves, as well as all the species of Chiton, are eyeless.

Some deep-sea animals are brightly and deeply-coloured. In the Challenger Expedition shrimps "of an intense bright scarlet colour" were obtained in very great abundance; and many Holothurians or Sea-cucumbers were of a "deep lpurple" hue. The same observation occurred to me in the Porcupine and Travaillevt Expeditions.

6. Temperature. - The highest temperature of the sea-bottom observed in the Challenger voyage at depths over 1000 fathoms was $50^{\circ} .5 \mathrm{Fahr}$, in $255^{\circ}$ fathoms; the lowest was $32^{\circ} \cdot \mathrm{I}$ only, in I 950 fathoms. The average bottom-temperature at great depths does not much exceed the freezing-point; but life does not appear to be affected by that circumstance. In the Arctic Expedition of 1875 I found an abundance and variety of animals in icy cold water.

7. Depth. - The average depth of the ocean between latitudes $60^{\circ} \mathrm{N}$. and $60^{\circ} \mathrm{S}$. is nearly three miles, or 2500 fathoms. The greatest depth which has been ascertained by sounding is five miles and a quarter, or 4620 fathoms, and occurs in the North. west Pacific Ocean; it is nearly equal to the height of Mount Everest, the highest known mountain, in the proportion of 27,720 to 29,000 feet.

8. Inequalities of the Sea-bottom.-The operations of the Telegraph Construction and Maintenance Company have materially added to our knowledge of the shape and contour of the floor of the ocean. They have shown us that the bed of the sea is quite as uneven as the surface of the land, and that it represents the same mountains, hills, gorges, and valleys, equally 
diversified in the one case by oceanic currents on the surface as well as on the bottom, and in the other by foaming rivers and gentle streams. I will give a few instances of such inequalities in the North Atlantic. While repairing in 1878 the AngloAmerican Cable, a tract of rocky ground was discovered, about 100 miles in length, in the middle of the North Atlantic, between $33^{\circ} 50^{\prime}$ and $36^{\circ} 30^{\prime}$ West longitude, and about $5 \mathrm{I}^{\circ} 2 \mathrm{O}^{\prime}$ North latitude. Within a distance of eight miles the shallowest sounding was 1370 , and the deepest 2230 fathoms, a difference of 860 fathoms, or 5160 feet; within four miles the difference was 3180 feet, and within half a mile 1380 feet. There are also the Laura Ethel Bank, with a depth of only 36 fathoms, and the Milne Bank, with 8I fathoms, both about 550 miles from Newfoundland, which is the nearest continental land. Other instances are the Josephine Bank, with 82 fathoms, and Gettysburg Bank, with 30 fathoms, the distance of the former from Cape St. Vincent being 250 , and the latter 130 miles, with intermediate depths of from 1700 to 2500 fathoms. The soundings in the Bulldog Expedition also gave 748 between II 68 and 1260 fathoms, and the Valorous soundings gave 690 between $145^{\circ}$ and 1230 fathoms in another part of the North Atlantic and very far from any land.

A glance at the large series of diagrams of the Challenger soundings will at once serve to convince one of the extreme unevenness of the sea-bottom everywhere in the Atlantic and Pacific oceans. It would be difficult to find a greater degree of unevenness in any diagrams of the earth's surface, the total extent of which scarcely exceeds one fourth of that of the sea.

Diagrams to illustrate the inequalities of the sea-bottom in the case of the telegraph cable, and the irregularities of level in a similar extent of land in the Perthshire Highlands, are placed before you.

9. Deposits. - The floor of the ocean is covered by a more or less thick layer of ooze or mud, and of clays of different sorts and colours, which is inhabited by various animals. One of these deposits is called "Globigerina"-ooze, and is widely distributed over the bed of both the Atlantic and the Pacific. Another deposit is called "Red Clay," and is found at depths exceeding 2000 fathoms. Mr. Murray, one of the Challenger naturalists, has carefully worked out the deep-sea deposits which were observed and collected during the expedition. According to him the Globigerina-ooze occurred in the North Atlantic at fortynine stations, from depths between 780 and 2675 fathoms; in the South Atlantic at six stations, from depths of between I 375 and 2150 fathoms; and in the Pacific Ocean at twenty-two stations, from depths of between 275 and 2925 fathoms. $\mathrm{He}$ also mentions other deposits, viz. Coral-mud, Radiolarian ooze, and Diatomaceous ooze. Mr. Murray also says that volcanic products, such as pumice, lava, and scoriæ, as well as the peroxide of manganese, are universally spread over the bottom of the dee, sea ; and, in consequence of copper, cobalt, and nickel having been detected in the clays, he was tempted to suggest the presence of meteoric or cosmic dust in those deposits.

An animated, but quite amicable, controversy has of late years taken place as to whether Globigerina (from which the firstmentioned ooze has taken its name) lives only on the bottom or on the surface of the sea, or on both of them. You will doubtless ask, What is a Globigerina? It is a microscopie shell, consisting of a few globular cells, which are added together in the course of growth, the smallest cell being the original one or nucleus, and the largest being the last formed. All the cells are full of a protoplasmic substance called sarcode, which is amorphous or has no definite structure-no head, no limbs, no heart, viscera, muscles, or nerves. Its entire body is a stomach, and nothing but a stomach. The same kind of sarcode forms the living pulp of sponges, which have a horny or glass-like skeleton instead of a shell. The Globigerina is a member of an extensive and extremely variable class of invertebrate animals called Foraminifera; and this class, as well as sponges, belong to a kingdom called Protozoa, the name of which imports not that it was the earliest form of life, but that its organisation is of the very primary or simplest kind. The cells of the Globigerina are in their living state covered with the most delicate spines of comparatively great length, which are set outwards, and probably serve to keep at a respectful distance all predatory animals of an equally minute size. Between these spines some of the sarcode is occasionally, if not habitually, protruded at the will of the animal through very fine pores of the shell, which gave rise to the name Foraminifera. Such prolongations or expansions of the sarcode are called pseudopodia, and are used for capturing and taking into the body or stomach animal or vegetable particles which serve for food, and are engulfed in the internal sarcode. Having premised thus much, and in the hope that my description may be tolerably intelligible to those who have not, like myself, studied the Foraminifera, I will proceed with my account of the controversy. I have frequently taken with a towing-net on the surface of the sea a multitude of floating Globigerina, which were certainly alive and showed their pseudopodia as well as their long and thick-set spines. Major Owen and Kieut. Palmer, who especially studied the surface-fauna of the Atlantic, observed and have published the same facts. ${ }^{1}$ Therefore when, in the joint report of my colleagues and myself to the Royal Society, on the results of the first Porcupine Expedition in 1869 , it was stated or strongly inferred that the Globigerine really " inhabit the bottom on which they are found in such extraor. dinary abundance," and that the hypothesis accounting for such accumulation by their having fallen to the bottom after death, their lives having been passed at or near the surface, was conclusively disproved, I ventured to record my dissent from that conclusion. The observations of Mr. Murray, one of the naturalists in the Challenger Expedition, have fully confirmed the hypothesis that Globigerina lives on the surface; and Sir Wyville Thomson now admits ${ }^{2}$ it as an established fact. But Dr. Carpenter is not satisfied. $\mathrm{He}$ is of opinion that "whilst the Globigerina are pelagic in an earlier stage of their lives, frequenting the upper stratum of the ocean, they sink to the bottom whilst still living, in consequence of the increasing thick ness of their calcareous shells, and not only continue to live on the sea-bed, but probably multiply there-perhaps there exclusively." 3 I must say that I am not convinced by the instances and arguments which he adduced in support of his opinion. There is no question that a great many species of Foraminifera live always on the sea-bottom; but I do not know that any species of pelagic or surface-dwelling animal inhabits also the sea-bottom. Dr. Wallich found that the stomachs of star-fishes which came up with the sounding-line from I260 fathoms contained fresh-looking Globigerine, and that the latter were full of sarcode. This does not prove much, because sea-water is to some extent antiseptic or retards putrefaction. Many star-fishes feed like earthworms, and swallow quantities of organic and inorganic matter for the purpose of extracting nutriment from it. Sir Wyville Thomson says, in his paper "On Dredgings and Deep-Sea Soundings in the South Atlantic" (Proc. R. S. vol. xxii. p. 427), that the appearance of Globigerina and certain other Foraminifera, "when living on the surface, is so totally different from that of the shells at the bottom that it is impossible to doubt that the latter, even although they frequently contain organic matter, are all dead." Mr. Murray adds (Proc. R. S. vol. xxvi. p. 535):- "No living specimen of a Globigerina, an Orbulina, a Pitlvinulina, or of the new genera found on the surface, which undoubtedly came from the bot:om, has yet been met with. The foregoing observations appear to justify the opinion that these organisms live only in the surface and subsurface waters of the ocean."

I will not however presume to assert that Dr. Carpenter may not be right ; but is he justified in taking for granted " that the onus probandi rests on those who maintain that the Globigerine do not live on the bottom"? It is rather difficult to prove such a negative.

'The colour of the "Red Clay" was attributed by Mr. Murray to the presence of oxide of iron.

Mr. Etheridge obligingly examined some of the pebbles and minerals which I had dredged in the Valorous Expedition at depths of from 690 to 1750 fathoms. He reported that many of them were " most likely derived from Iceland." If this were the case, the pebbles and minerals might have been transported by a deep submarine current.

The deposits in very deep water, and beyond the range of fluviatile and tidal action, are so slight as to be almost filmy, and are chiefly composed of the skeletons or hard parts of Globigerine, Diatoms, and Radiolarie. The subjacent layer of mud or ooze, where it is beyond the scope of river action, may have been formed from the ruins of a sunken continent.

The proportion of carbonate of lirne contained in the deepsea mud or ooze of the North Atlantic, which was procured in the first two cruises of the Porcupine Expedition of r 869, slightly differed. In a sample from 1443 fathoms, dredged off the west

I Fournal of the Linnean Society, vol. ix. p. 147.

2 Proc. Roy. Soc. vol, xxiii.p 34.

3 Ibid. p. 235 . 
coast of Ireland in the first cruise, the proportion given by the late Mr. David Forbes was only about one-half, while in another sample from 2435 fathoms, dredged off the south coast of Ireland in the second cruise, Mr. Hunter found a little over 60 per cent.

As to a mysterious deposit called Bathybius, Mr. Buchanan, who had charge of the chemical work on board the Challenger, proved by careful and repeated analysis that this substance was not organic; and he "determined it to be sulphate of lime, which had been eliminated from the sea-water, always present in the mud, as an amorphous precipitate on the addition of spirit of wine." Mr. Murray came to the same conclusion; and the lifeless and inorganic nature of Bathybizs may now be considered settled. This gelatinous slime was once imagined to be primordial, and to constitute the basis of life. But the sea-bed is the tomb of past generations, not the womb of creation.

10. Gcological.-The late Sir Charles Lyell says, in the sixth edition of his "Elements of Geology" (1865), "that white chalk is now forming in the depths of the ocean, may now be regarded as an ascertained fact, because the Globigerina bulloides is specifically undistinguishable from a fossil which constitutes a large part of the chalk of Europe." He assumed that the Globigerina inhabited the ooze on the sea-bed. Edward Forbes and other geologists had initiated and adopted the same view that Chalk was a deep-sea deposit. In my Presidential Address to the Biological Section of the British Association at the Plymouth Meeting in 1877 , I ventured to question the validity of this theory, and especially that which my colleague and friend Sir Wyville Thomson s:arted as to the "continuity of the Chalk" from the Cretaceous to the present period. I there endeavoured to show that the Chalk differed in composition from the Atlantic mud, and that the fauna of the Chalk formation represented shallow and not deep water. My view has, I am glad to say, been to some extent admitted by Sir Wyville Thomson in his "Report on the Scientific Results of the Voyage of H.M.S. Challenger," when he speaks (pp. 49 and 50) of the belt of "shallower water" during the Cretaceous period. At all events, $\mathrm{Mr}$. Wallace has lately accepted and confirmed my opinion ${ }^{1}$ it is highly probable that the Gault, which underlies the Chalk and is the lowest member of the Upper Cretaceous formation, was a deep-water deposit, because it abounds in small shells of the Arca and Corbula families, which are wanting in the Chalk; as well as in Ammonites and other free-swimming Cephalopods.

Mr. Sollas, indeed, in his paper "On the Flint Nodules of the Trimmingham Chalk" (Annals and Magazine of Natural History for December, 1880) believes that some deep-sea mud is analogous with the Chalk. He is aware that the former contains siliceous organisms and the latter none; and he supposes that the flints had been in some way derived from these organisms. But how flints originated and were formed is still a vexed question. Mr. Sollas is perhaps our best authority on Sponges; but he states (p. 444) that "the bottom-water of the sea is remarkably free from organic matter." This statement does not agree with the analyses of the bottom-water of the sea which were made by Mr. Lant Carpenter, Dr. Frankland, and Mr. Buchanan, the chemist of the Challenger, nor with the observations of Sir Wyville Thomson in his "Depths of the Sea," in which he says (p. 46) "the bottom of the sea is a mass of animal life."

Several species of Mollusca which were previously known as fossil only, and were supposed to be extinct, have lately been dredged by myself and others from the bottom of the Atlantic. Some of these same species had been described and figured by Prof. Seguenza of Messina from Pliocene beds in Sicily. I have no doubt that many more, perhaps all, of such fossil species will be hereafter discovered in a living state by means of deepsea explorations.

Some geologists, and especially of late years, have advocated the theory that oceans have continued for an enormously long period to occupy the same areas that they still occupy. Mr. Darwin was, I believe, the first to broach this idea. He says, in the chapter "On the Imperfection of the Geological Record," "We may infer that where our oceans now extend oceans have extended from the remotest period of which we have any record and, on the other hand, that where continents now exist large tracts of land have existed, subjected, no doubt, to great oscillations of level, since the earliest Silurian period." There does not seem to be any fact adduced or reason given for either of the abuve inferences.

$$
\text { x "Island Life." }
$$

If the present oceans and continents have remained unchanged since the Silurian period, how can we account for the widespread distribution of fossiliferous formations, Palæozoic, Mesozoic, Cainozoic or Tertiary, and Quaternary or Kecent, miles in thickness, all over Europe, Asia, Africa, Australasia, and New Zealand? All oceanic islands are of volcanic origin; but some of them contain Miocene fossils. These formations are chiefly marine, both deep water and shallow; and they necessarily imply the presence of oceans in those parts of the globe which are now continents and dry land. All the "secrets of the deep" will probably never be revealed to man, nor is he likely to know what terrestrial formations underlie the floor of the mid ocean.

In my paper " On the Occurrence of Marine Shells of Existing Species at different Heights above the Present Level of the Sea," which was published in the Quarterly Fournal of the Geological Society for August 1880, I stated that many existing species of Mollusca which inhabit great depths only are found in a fossil state at considerahle heights above the present level of the sea, so as to show an elevation equal to nearly 12,000 feet, and that such elevation must have taken place at a very late and comparative!y recent stage of the Tertiary or Post-Tertuary epoch. In the face of facts like this, can we rightly assign to the present oceans that geologically remote antiquity which is claimed for them?

I I. Incidental.-Clarence's dream of wrecks, corpses, wonderful treasures, and

$$
\begin{aligned}
& \text { reflected gems } \\
& \text { That woo'd the slimy bottom of the deep, } \\
& \text { And mock'd the dead bones that lay scatter'd by," }
\end{aligned}
$$

has not yet, I believe, been realised by any dredger. I have in this way explored for between forty and fifty years all our own seas, besides a considerable part of those on the coasts of North America, Greenland, Norway, France, Spain, Portugal, Morocco, and Italy; but I have never found anything of value except to a naturalist, nor any human bone, although many thousard human beings must have perished in those seas.

I 2 Concluding Remarks. - To give a better idea of the ocean and of its life in the depths as well as on the surface, let me strongly recommend my hearers to read Mr. Moseley's admirable volume entitled "Notes of a Naturalist on the Challenger." His graphic account of this marvellous voyage far surpasses in interest (to say nothing of accuracy) every work of fiction or imagination, and it has not the melancholy dulness of most books on history and travels.

The sutject of this lecture is inexhaustible; and, as our knowledge of it becomes more extended, we must continually say with Seneca, "Our predecessors have done much, but have not finished. Much work yet remains, and much will remain; nor to any one, born after a thou:and ages, will be wanting the opportunity of still adding something." Such increase of knowledge must tend to confirm cur acknowledgment, with a reverential awe, of that Great Creator whose wondrous works are dimly seen in every form of life, marine and terrestrial, and especially in

"all that glides

Beneath the wave, yea, in the wave itself, And mighty waste of waters."

\section{GAS AND ELECTRICITY AS HEATING $A G E N T S^{1}$}

\section{I.}

March 14, I878, I had the honour of addressing you "On the Utilisation of Heat and other Natural Forces." I then showed that the different forms of energy which Nature has provided for our uses had their origin, with the single exception of the tidal wave, in solar radiation; that the forces of wind and water, of heat and electricity, were attributable to this source, and that coal formed only a seeming and not a real exception to the rule, - being the embodiment of a fractional portion of the solar energy of former geological ages.

On the present occasion I wish to confine myself to one branch only of the general subject, namely, the production of heat energy. I shall endeavour to prove that for all ordinary purposes of heating and melting, gaseous fuel shonld be resorted to for the double reason of producing the utmost economy and of doing away with the bugbear of the present day, the smoke nuisance; but that for the attainment of extreme degrees of heat

${ }^{x}$ A lecture by C. William Siemens, D.C.L., LL.D., F.R.S., on January 27, in St. Andrew's Hall, Glasgow, under the auspices of the Glasgow
Science Lecture Association. 